\title{
Impact of metal mining on per capita family income in Peru
}

\author{
René Paz Paredes Mamani ${ }^{1}\left[\right.$ [D $\cdot$ Roberto Arpi Mayta $^{1} \cdot$ Roberto Chávez Flores $^{1} \cdot$ Faustino Ccama Uchiri $^{2}$
}

Received: 25 July 2021 / Accepted: 21 December 2021 / Published online: 8 March 2022

(c) The Author(s) 2022

\begin{abstract}
The objective of the research was to measure the impact of metal mining production on per capita family income at the district level, during the period 2003 and 2019. For this purpose, the data from the United Nations report and the econometric methodology of difference in differences were used with and without spatial effects. The results without spatial effect show that the impact of mining on monthly per capita family income between 2003 and 2019 was 207.42 soles. However, considering the effects of spatial spillover, the total impact was 291.61 soles, which is decomposed into a direct and indirect impact of 189.77 soles and 101.84 soles, respectively. Likewise, the results suggest that there is a total impact of 77.25 soles on the per capita family income of the neighboring non-mining district. These results suggest that there is ample space for the design and implementation of public policies for the mining sector.
\end{abstract}

Keywords Mining $\cdot$ Income $\cdot$ Impact $\cdot$ Extractive $\cdot$ Districts $\cdot$ Peru

\section{Introduction}

Peru is one of the most important countries in Latin America and the world in mining production and export (Aron and Molina 2020). Worldwide, Peru ranks second in the production of copper, silver, and zinc, while in Latin America, it occupies the first place in the production of gold, zinc, lead, tin, diatomite, analucite, and selenium (Appendix Table 5).

"Mining is an extractive activity that takes place all over the world" (Osinergmin, 2017); it influences the standard of living of the population through the impact on the environment and socioeconomic status (Kitula 2006; Ticci and Escobal 2015); it is a source of environmental

René Paz Paredes Mamani

rpparedes@unap.edu.pe

Roberto Arpi Mayta

rarpi@unap.edu.pe

Roberto Chávez Flores

rchavez@unap.edu.pe

Faustino Ccama Uchiri

faustino.ccama47@gmail.com

1 Universidad Nacional del Altiplano, Puno, Avenida Floral 1153, Puno 51 Puno, Peru

2 Universidad Nacional Autónoma de Huanta, Jr. Manco Cápac N497, Huanca, 05121 Huanta, Peru liabilities and socio-environmental conflicts (Dammert and Molinelli 2007). The large-scale mining industry in general is relatively capital-intensive. "Capital is requerid to conduct exploration, feasibilility studies, design mines, purchase mining equipament, procesing plants, develop mine infraestructura or recapitalise producing mines" (Seeger 2019). The artisanal and small-scale mining (ASM) is a formal or informal sector with limited available information on production, revenues, explorations, and extraction, which is normally low capital-intensive and uses high laborintensive technology (Sidorenko et al. 2020). Nevertheless, ASM mining is important for rural livelihoods for many rural and regional communities (Loayza and Rigolini 2016; Osumanu 2020; Ticci and Escobal 2015).

From a macro-perspective, the contribution of the mining sector to the economy includes employment, exports, fiscal revenues, road infraestructura, livelihoods, investment, and contribution to GDP through linkage industries. The dynamism of the mining sector in Peru, at the macroeconomic level, has contributed to exports and the growth of the economy. Between 2010 and 2019, the GDP of the mining sector grew at an average annual rate of $3.9 \%$, and in the period $2010-2020$, it explained $10 \%$ of the national GDP (IPE 2021; MINEM 2019); likewise, it has contributed $59.26 \%$ of total exports (Appendix Table 5).

At the microeconomic level, mining activity has contributed positively to household income, employment, 
education, and food expenses and negatively to the environment where mining is located (Balanay et al. 2014; Landa 2017; Loayza and Rigolini 2016; Torres 2015). In the case of Arequipa in Peru, they show that mining activity in a district increases the probability that households access basic services (water, hygienic services, and electricity) but decreases the likelihood that people engaged in this activity achieve a university higher education (Nolazco and Figueroa, 2015).

The mining activity caused by the mining boom can influence the economic and social well-being of households through the following channels: first, the demand for labor and input by the mining company and the effect on nonmining sectors through back and forth linkage; second, the fiscal channel through the transfer of fiscal revenues and royalties to local governments; third, through mining company development projects and social responsibility initiatives; finally, through the environmental channel that generates the extraction of the mining resource (Antoci et al. 2019; Gamu et al. 2015; Ticci and Escobal 2015).

From a technical regulatory point of view, mining activity in Peru is classified into two large groups: formal mining and non-formal mining. Non-formal mining in turn is subdivided into informal mining and illegal mining. "Formal mining is one that complies with all the mining, environmental, social, labor, tax requirements and permits established in legal regulations and includes large-scale mining, mediumscale mining, small-scale mining and artisanal mining" (Vargas 2014). "This activity carried out by a person, natural or legal, who has authorization to start or restart mineral exploration, exploitation and/or benefit activities and/or benefit concession title issued by the competent authority" (MINEM 2017). Informal mining is one that does not comply with permits to carry out mining activity, operates in non-prohibited areas, has a declaration of commitment and is in the process of formalization, and includes the small mining producer ${ }^{1}$ (SMP) and the artisanal mining producer ${ }^{2}$ (AMP) (Vargas 2014). This activity is carried out by natural or legal persons or a group of organized persons who have started a formalization process. This type of mining is carried out using equipment and machinery that do not correspond to the characteristics of the mining activity of the

\footnotetext{
1 "The small mining producer is the natural person-or the legal person made up of natural persons or mining cooperatives or central mining cooperatives-who are usually engaged in the exploitation and/or direct benefit of minerals" (Wiener 2019).

2 "The artisanal mining producer is the natural person-or the legal person made up of natural persons or mining cooperatives or central mining cooperatives - who habitually dedicate themselves and as a means of support to the exploitation and/or direct benefit of minerals, and who carry out their activities with manual methods and/or basic equipment"(Wiener 2019).
}

small mining producer or artisanal mining producer or without complying with the requirements of the administrative, technical, social, and environmental regulations that govern such activities in zones not prohibited for mining activity (MINEM 2017). Illegal mining is one that does not comply with the permits to carry out mining activity, operates in prohibited areas and/or uses large capacity machinery, and is subject to interdiction and eradication (Vargas 2014). Illegal mining is carried out by a natural or legal person or a group of people organized using equipment and machinery that does not correspond to the characteristics of the mining activity carried out by the SMP or AMP or without complying with the requirements of the regulations and of an administrative, technical, social, and environmental nature that govern these activities (MINEM 2017).

According to ownership, mining activity is classified into two large regimes: the general regime and the regime of small mining and artisanal mining. The general regime includes medium- and large-scale mining, and the artisanal and small mining (ASM) regime includes the small mining producer (SMP) and the artisanal mining producer (AMP) (Wiener 2019). Large mining and medium mining are formal, while ASM is formal, informal, and illegal; most of it is informal and ilegal, and ASM carries out extractive activities on a small scale; however, the rise in mineral prices in recent decades has boosted this activity even outside of the law and current institutions (MINAM 2016). ASM's mining activity has become more dynamic, mainly in the departments of Madre de Dios, Puno, Ica, Ayacucho, Arequipa, and La Libertad, respectively (Argota et al. 2014).

The department of Madre de Dios, with greater intensity of informal gold extraction, attracts many migrants who moved to the Huepetue district basin from the Andean highlands, to work in mining as a means of subsistence. However, ASM is not exclusively a poverty-driven activity. There is an elite of small-scale mining entrepreneurs with a "resource nationalist" discourse who oppose large-scale mining projects (Cortés-McPherson 2019). Rich miners move easily between the formal, informal, and illegal world, in the middle of a city with unpaved streets and a lack of basic services, yet the local industry produces 9 tons of gold per year (Cortés-McPherson 2019). Regarding deforestation due to small mining and artisanal minerals, Espejo et al. (2018) estimate that in the period 1984-2017 in the southern Peruvian Amazon 100 thousand ha have been deforested, of which 10\% occurred in 2017 and 53\% between the years 2011 and 2017.

Informal and illegal gold production generally ranks third or second nationally. It is estimated that between 300 and 500 thousand of the number of artisanal gold miners throughout the country and that 1 million people (3\% of the country's population) are directly or indirectly linked to the activity, of which it is estimated that the $90 \%$ are informal 
Fig. 1 Average district per capita family income: 2003 2019. Source: UNDP 2003, 2007, 2011, 2015 and 2019. Elaboration. Own

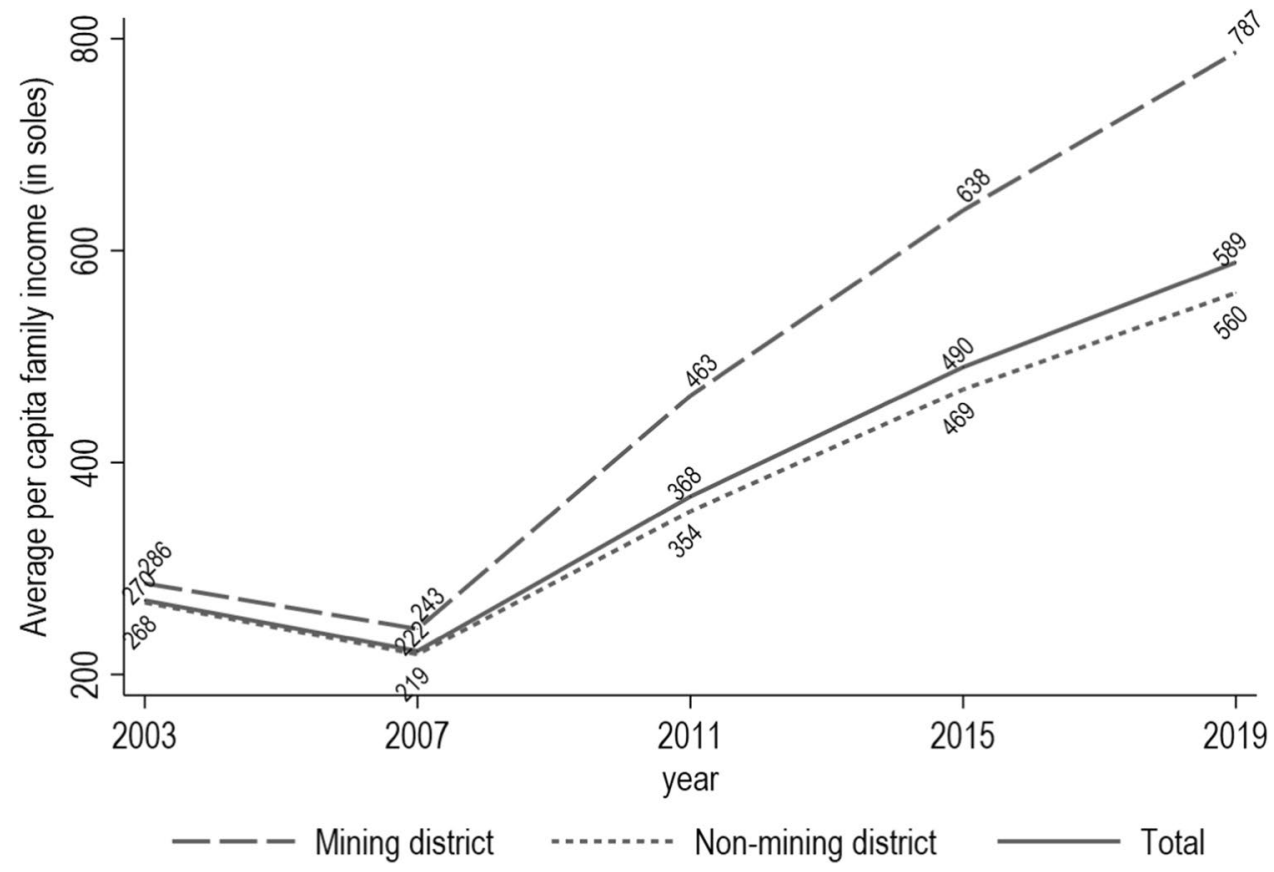

and illegal miners (Cano 2020). In 2012, with the aim of formalizing ASM's informal miners, the Comprehensive Mining Formalization Registry (REINFO) was created, where natural or legal persons carry out the mining activity of exploitation and/or benefit. Until April 24, 2021, 88,729 miners were registered for the formalization, of which the majority correspond to the southern departments: Arequipa (21.40\%), Ayacucho (12.04\%), Puno (10.80\%), Apurímac (10.4\%), and Madre de Dios (8.81\%) (MINEM 2021).

The dynamism of the mining sector, driven by the extraordinary increase in international mineral prices since 2003, has increased the fiscal resources of local district and provincial governments above the levels observed before the price boom (Maldonado 2011). In the case of the southern Peruvian Amazon, where artisanal mining predominates, the dynamism of gold extraction is due not only to the rise in international prices, but also the construction of the Interoceanic Highway (Manrique and Sanborn 2021). However, small-scale mining and artisanal mining have multiple origins, such as the economic crisis during the $1970 \mathrm{~s}$ and 1980s, easy access to exploitation areas, low monetary and technological investment, colonization, and emigration policies, as well as the emigration generated by political violence to areas with little state presence (Manrique and Sanborn 2021).

Figure 1 shows the evolution of Peru's average monthly district per capita family income between 2003 and 2019. As can be seen in the figure, per capita family income increased steadily from 2007 onwards. The per capita family income of the mining districts increased at a faster rate than that of non-mining districts during this period. In 2003, the income gap in favor of the mining districts was 18 soles; this gap increases to 227 soles in 2019. The average income of the districts evolves at the same speed as the total income of the country.

In relation to the distribution of per capita family income in the district of Peru, in 2013-2019, Fig. 2 shows that the income distribution curves tend to flatten over the years, which means that there is an increase in the dispersion of the incomes. Between 2003 and 2007, it is observed that there is a greater increase in the dispersion of income, despite the fact that in this period the average family income per district capital had a slight downward variation. These results are consistent with the findings of Escobal and Ponce (2012)

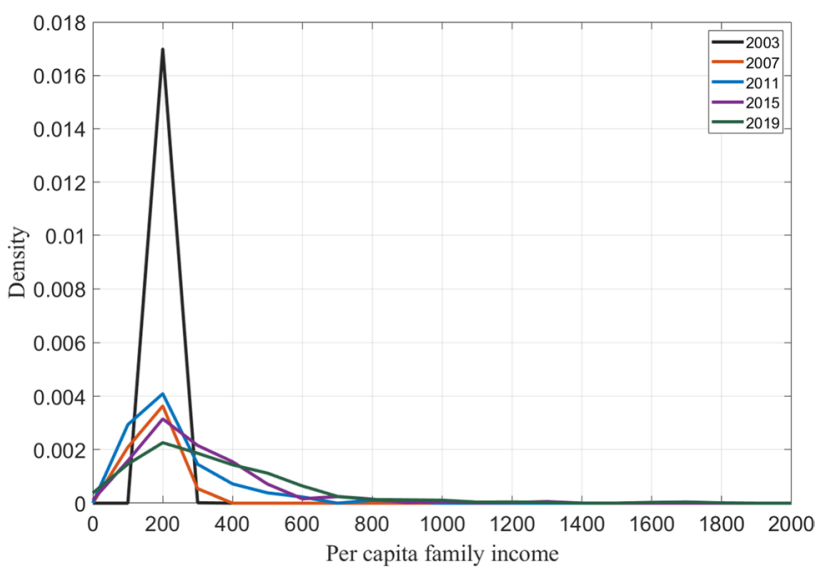

Fig. 2 Distribution of district per capita family income. Source: UNDP 2003, 2007, 2011, 2015 and 2019. Elaboration. Own 
(a)

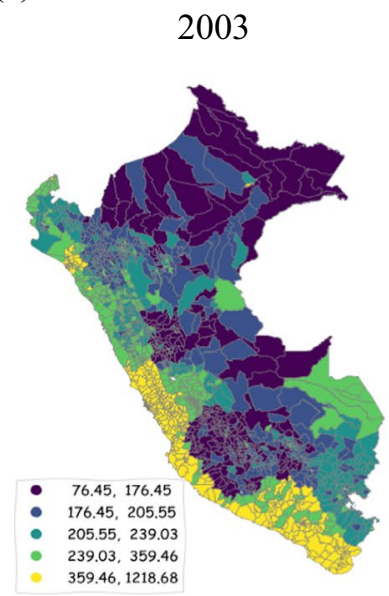

2019

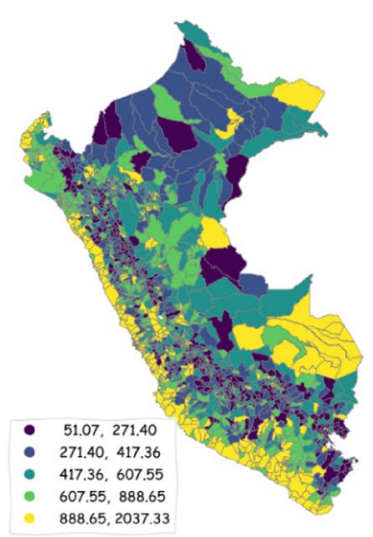

(b)

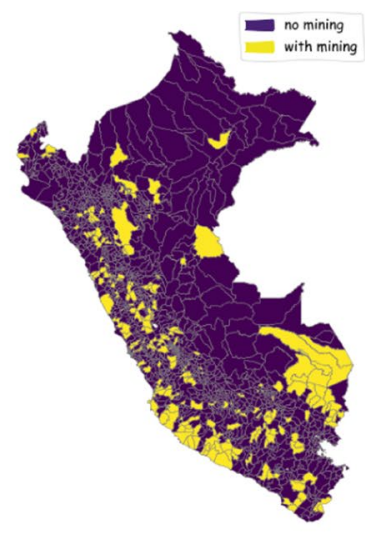

Fig. 3 District per capita family income and metal mining-producing districts. a District per capita family income. b Districts with metal mining. Source: UNDP 2003 and 2019. Elaboration. Own

that show that in the period 2004-2007, there is a stagnation in the Gini coefficient and a worsening in the polarization and segregation indicators. The authors show a trend of segregation and spatial polarization in favor of large cities as opposed to small cities and towns, as well as the polarization between indigenous and non-indigenous groups. As of 2007, the distribution curves tend to flatten over the years but in a more moderate way.

In the period 2003-2019, the district's per capita family income increased by an average of 319 soles; in the mining districts, this increase was 500 soles. However, the minimum and maximum values of the variation in income fluctuate between -460 and 1471 considering all the mining and non-mining districts and between -281 and 1471 in the mining districts. In 2003, the year in which the rise in the price of minerals began, the distribution of income at the district level was more homogeneous, but the majority of districts were poor. The richest quintile had a per capita family income between 359 and 1216 soles; these districts are located mainly on the southern coast of Peru and near mining sites (Fig. 3a). In 2019, the districts of the richest quintile in Peru have per capita family income levels that vary between 889 and 2037 soles. However, other districts of the sierra and jungle are incorporated into this group, which are located mainly near the mining centers of Arequipa, Madre de Dios, Puno, and Apurimac (Fig. 3a and b).

The mining districts ${ }^{3}$ in which per capita income increased above 1,000 soles are Amanea in Puno (1,471 soles), Chicla in Lima (1,339 soles), Torata in Tacna (1,335

\footnotetext{
3 The identification of mining districts was made based on the information available on mineral production from the Ministry of Energy and Mines.
}

soles), Huepetuhe in Madre de Dios (1305 soles), Morococha in Junín (1283 soles), Samegua in Moquegua (1181 soles), Ite in Tacna (1147 soles), Bella Unión in Arequipa (1091 soles), Ilabaya in Tacna (1054 soles), Rio Grande in Arequipa (1040 soles), and Rioja in San Martín (1012 soles).

On the contrary, the mining districts where income decreased the most are San Juan de Tantaranche in Lima (281 soles), Ongón in La Libertad (135 soles), Tumay Huaraca in Apurímac (101.52 soles), Usquil in La Libertad (98 soles), Sarín in La Libertad (93 soles), Layo in Cusco (27 soles), Catilluc in Cajamarca (27 soles), San Miguel de Aco in Ancash (13 soles), and Santa Ana de Tusi in Pasco (7 soles).

In this context, the objective of the research is to quantify the effect of mineral extraction on the per capita income level at the district level in Peru in the period 2003 and 2019.

\section{Methodology}

To measure the impact of metal mining on the level of per capita family income at the district level, the following econometric model of differences in differences is proposed (Bernal and Peña 2011):

$y_{i t}=\beta_{1}+\beta_{2} D_{i}+\gamma T_{i}+\delta\left(T_{i} * D_{i}\right)+e_{i t}, i=1,2, \ldots, 110 ; t=1,2$

where in the per capita family income of the household, it is a dichotomous variable that takes the value of 1 if the district is a producer of metallic minerals (treatment group) and 0 if it is not a producer of minerals (control group); it is a dichotomous variable that takes the value of 0 at $t=1$ (period prior to implementation) and 1 at $t=2$ (period after 
Table 1 Expected income of the treatment and control group before and after treatment

\begin{tabular}{llll}
\hline & Treatment & Control & Time \\
\hline$t=1$ (baseline) & $E\left(y_{i, T=0} \mid D_{i}=1\right)=\beta_{1}+\beta_{2}$ & $E\left(y_{i, T=0} \mid D_{i}=0\right)=\beta_{1}$ & $T_{i}=0$ \\
$t=2$ (tracing) & $E\left(y_{i, T=1} \mid D_{i}=1\right)=\beta_{1}+\beta_{2}+\gamma+\delta$ & $E\left(y_{i, T=1} \mid D_{i}=0\right)=\beta_{1}+\gamma$ & $T_{i}=1$ \\
\hline
\end{tabular}

implementation of treatment or follow-up) (Bernal and Peña 2011). From the equation, the expected per capita family income is obtained for the treatment and control group for periods 1 and 2, which is shown in Table 1 and graphically illustrated in Fig. 4.

The impact of the program by the difference-in-difference method would be given by

$$
\begin{aligned}
\delta & =\left[E\left(y_{i, T=1} \mid D_{i}=1\right)-E\left(y_{i, T=0} \mid D_{i}=1\right)\right] \\
& -\left[E\left(y_{i, T=1} \mid D_{i}=0\right)-E\left(y_{i, T=0} \mid D_{i}=0\right)\right]
\end{aligned}
$$

When writing the estimator of Eq. (2), for the sample analog, we have

$\delta=\left[\left(\bar{y}_{2} \mid D_{i}=1\right)-\left(\bar{y}_{1} \mid D_{i}=1\right)\right]-\left[\left(\bar{y}_{2} \mid D_{i}=0\right)-\left(\bar{y}_{1} \mid D_{i}=0\right)\right]$

That is, the impact is the result of the difference in the sample mean between the treatment group and the control group in the period 2 minus the difference in the sample mean between the treatment group and the group of control in period 1. Equation (3), alternatively, can be written in terms of differences as

$\delta=\left[\Delta \bar{y} \mid D_{i}=1\right]-\left[\Delta \bar{y} \mid D_{i}=0\right]$

where $\Delta \bar{y} \mid D_{i}=1$ and $\Delta \bar{y} \mid D_{i}=0$ are the variations in the outcome variable in the treatment and control groups, respectively. In Eq. (4), there is a double difference. The first, $\Delta \bar{y} \mid D_{i}=1$ and $\Delta \bar{y} \mid D_{i}=0$. The second difference is given by the differences between the previous ones, that is, $\left(\Delta \bar{y} \mid D_{i}=1\right)-\left(\Delta \bar{y} \mid D_{i}=0\right)$. The second difference aims to control the factors that vary over time (Bernal and Peña 2011).

To estimate the effect of mining production on the district's per capita family income, Eq. (5) is formulated, controlling for the geographic altitude and the surface of the district:

$y_{i t}=\beta_{1}+\beta_{2} D_{i t}+\gamma T_{i t}+\delta\left(T_{i t} * D_{i t}\right)+\alpha_{1}$ Altitude $_{i}+\alpha_{2}$ Surface $_{i}+e_{i t}$

However, the mining districts not only benefit from the same mining activity, but also from the mining canon (MC) that local governments receive. Likewise, mining can influence family income in neighboring districts through the demand for employment or other inputs and its multiplier effect in non-mining sectors through backward and forward linkages or other spillover effects (Antoci et al. 2019).

The spillover effect is seen as the degree of development of a region is influenced by other regions. In this sense, Anselin (1988) took spatial dependence from the perspective of spillover externalities through a spatial econometric model. The model is decomposed into direct and indirect effects; the indirect effect reflects the spillover effect of the explanatory variable on the dependent variable. In order to capture the direct and direct impact of mining on the nonmining districts of the mining province, an econometric model is proposed with spatial spillover effects in the regressors and spatial dependence on the error term:
Fig. 4 Difference-in-difference estimator. Source: Prepared based on Abadie and Cattaneo (2018)

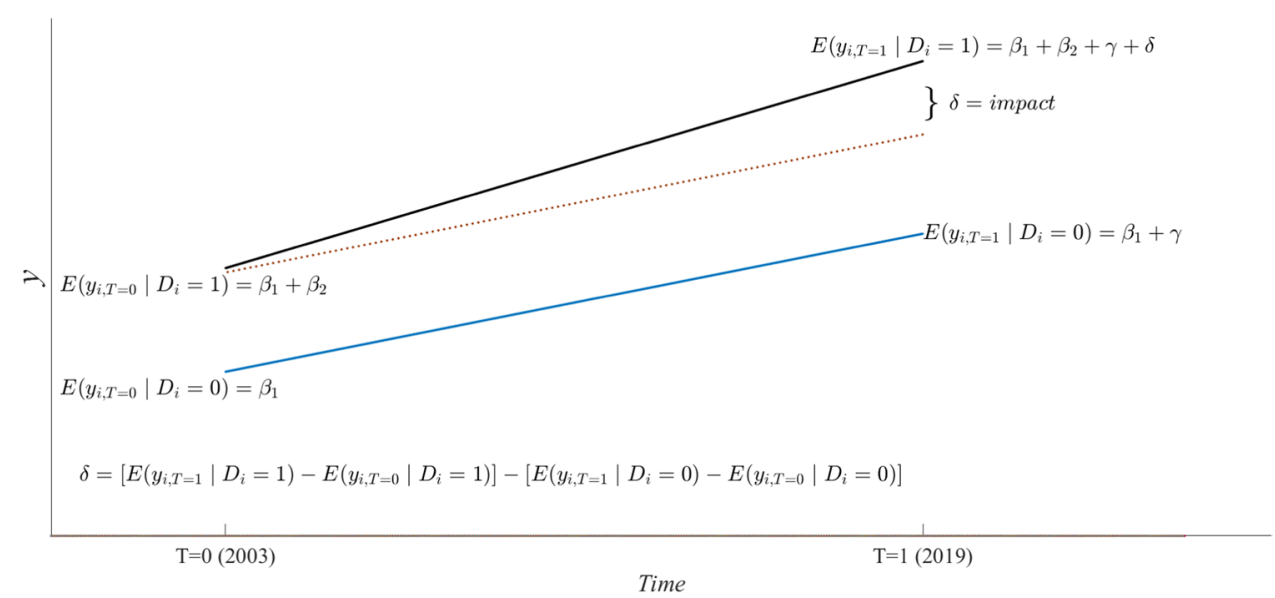


Table 2 Descriptive statistics

Table 3 Impact of mining on district per capita family income (Eq. (5))

\begin{tabular}{llllllll}
\hline Statistics & \multicolumn{9}{l}{ Per capita household income at the district level } & & Altitud & Superficie \\
\cline { 2 - 6 } & 2003 & 2007 & 2011 & 2015 & 2019 & & \\
\hline $\begin{array}{l}\text { Number of } \\
\text { observations }\end{array}$ & 1,828 & 1,833 & 1,834 & 1,867 & 1,874 & 1,874 & 1,874 \\
Media & 270 & 222 & 368 & 490 & 589 & 2237 & 690 \\
d.s & 136 & 111 & 238 & 291 & 365 & 1387 & 1922 \\
Variance & 18424 & 12373 & 56687 & 84557 & 133301 & 1923624 & 3695024 \\
Skewness & 2 & 2 & 2 & 1 & 1 & 0 & 6 \\
Kurtosis & 8 & 11 & 7 & 5 & 4 & 2 & 54 \\
\hline
\end{tabular}

Source: PNUD

\begin{tabular}{|c|c|c|c|c|c|c|}
\hline \multirow[t]{2}{*}{ Variable } & \multirow[t]{2}{*}{ Parameters } & \multicolumn{5}{|l|}{ Period } \\
\hline & & 2003-2007 & 2007-2011 & 2011-2015 & 2015-2019 & 2003-2019 \\
\hline Constant & $\beta_{1}$ & $\begin{array}{l}365.02 * * * \\
(0.00)\end{array}$ & $\begin{array}{l}378.05^{* * * *} \\
(0.00)\end{array}$ & $\begin{array}{l}592.67 * * * \\
(0.00)\end{array}$ & $\begin{array}{l}768.91 * * * \\
(0.00)\end{array}$ & $\begin{array}{l}478.86^{* * *} \\
(0.00)\end{array}$ \\
\hline$D$ & $\beta_{2}$ & $\begin{array}{l}21.96 * * * \\
(0.00)\end{array}$ & $\begin{array}{l}28.70 * * * \\
(0.00)\end{array}$ & $\begin{array}{l}115.97 * * * \\
(0.00)\end{array}$ & $\begin{array}{l}176.50 * * * \\
(0.00)\end{array}$ & $\begin{array}{l}24.53 * * \\
(0.01)\end{array}$ \\
\hline$T$ & $\gamma$ & $\begin{array}{l}-48.74 * * * \\
(0.00)\end{array}$ & $\begin{array}{l}134.99 * * * \\
(0.00)\end{array}$ & $\begin{array}{l}113.69^{* * *} \\
(0.00)\end{array}$ & $\begin{array}{l}91.78 * * * \\
(0.00)\end{array}$ & $\begin{array}{l}291.66^{* * * *} \\
(0.00)\end{array}$ \\
\hline$T D$ & $\delta$ & $\begin{array}{l}\mathbf{5 . 9 4} \\
(0.57)\end{array}$ & $\begin{array}{l}\mathbf{8 5 . 0 9} * * * \\
(0.00)\end{array}$ & $\begin{array}{l}\mathbf{5 9 . 2 5} * * \\
(0.02)\end{array}$ & $\begin{array}{l}\mathbf{5 6 . 8 8 *} \\
(0.07)\end{array}$ & $\begin{array}{l}\mathbf{2 0 7 . 4 2} \text { **** } \\
(0.00)\end{array}$ \\
\hline Altitud & $\alpha_{1}$ & $\begin{array}{l}-0.04 * * * \\
(0.00)\end{array}$ & $\begin{array}{l}-0.07 * * * \\
(0.00)\end{array}$ & $\begin{array}{l}-0.10^{* * * *} \\
(0.00)\end{array}$ & $\begin{array}{l}-0.13^{* * *} \\
(0.00)\end{array}$ & $\begin{array}{l}-0.09^{* * * *} \\
(0.00)\end{array}$ \\
\hline Surface & $\alpha_{2}$ & $\begin{array}{l}-0.01 * * * \\
(0.00)\end{array}$ & $\begin{array}{l}-0.01 * * * \\
(0.00)\end{array}$ & $\begin{array}{l}-0.02 * * * \\
(0.00)\end{array}$ & $\begin{array}{l}-0.03^{* * *} \\
(0.00)\end{array}$ & $\begin{array}{l}-0.02 * * * \\
(0.00)\end{array}$ \\
\hline$F$ & & 153.34 & 282.74 & 299.17 & 314.47 & 408.23 \\
\hline Prob $>F$ & & $(0.00)$ & $(0.00)$ & $(0.00)$ & $(0.00)$ & $(0.00)$ \\
\hline$R 2$ & & 0.22 & 0.35 & 0.32 & 0.32 & 0.41 \\
\hline$R C M$ & & 111.86 & 161.42 & 225.58 & 276.24 & 245.25 \\
\hline$N$ & & 3661 & 3667 & 3701 & 3741 & 3702 \\
\hline
\end{tabular}

$* * *, * *$ and $*$ denote significance level at $1 \%, 5 \%$ and $10 \%$.

$y_{i t}=\beta_{1}+\beta_{2} D 1_{i t}+\beta_{3} D 2_{i t}+\beta_{4} M C_{i t}+\gamma T_{i t}+\delta_{1}\left(T_{i t} * D 1_{i t}\right)+\delta_{2}\left(T_{i t} * D 2_{i t}\right)+\delta_{3}\left(T_{i t} * D 1_{i t}\right) . W+\delta_{4}\left(T_{i t} * D 2_{i t}\right) W+\beta_{5}$ Altitude $_{i}+\beta_{6}$ Surface $_{i}+e_{i t}$

$e_{i t}=\lambda W e_{i t}+u_{i t}$

where $D 1$ identifies the mining district, $D 2$ identifies the non-mining district found in the mining province, $C M$ is the per capita district mining canon, $W$ is a connection matrix or spatial continuity, $\beta_{1}$ is the constant term of the regression, $\beta_{1}$ is a parameter that captures the direction that exists between the per capita income between the mining and non-mining district, $\beta_{3}$ is a parameter that captures the difference in the per capita income of the non-mining district belonging to the mining province and the rest of the districts, $\delta_{1}$ measures the impact direct impact of mining on the per capita family income of the mining district, $\delta_{2}$ measures the direct impact of mining on the per capita family income of the non-mining district of the mining province, $\delta_{3}$ measures the indirect impact of mining on the per capita family income of the mining district, and $\delta_{4}$ measures the indirect impact of mining on the per capita family income of the non-mining district of the mining province.

\section{Data}

The UNDP data for Peru at the district level for the period 2003-2019 is used. Table 2 shows the descriptive statistics of the data used to evaluate the impact of mining. 
Fig. 5 Impact of mining on per capita income: 2003-2019

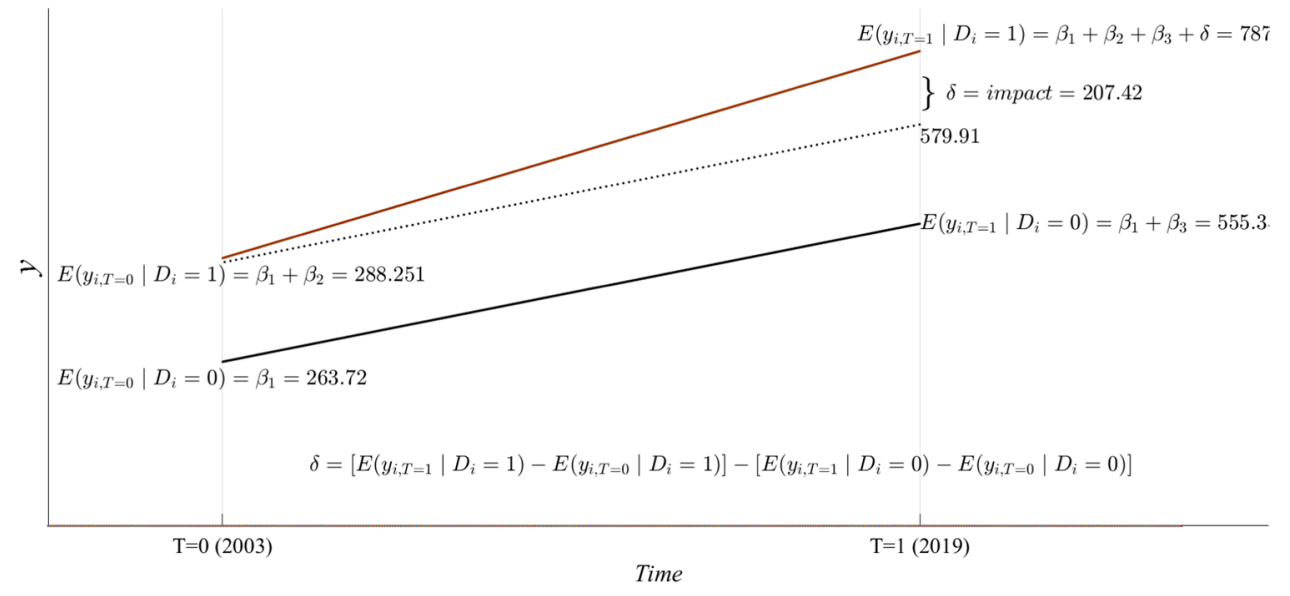

\section{Results and discussion}

The difference-in-difference model (Eq. (5)), estimated using the ordinary least squares method, is shown in Table 3 , having as control variables the geographical altitude of the district (meters above sea level) and the area of the district in square kilometers, and shows the following findings: mining activity has a positive and significant impact on per capita family income, in the period 2003 and 2019; the estimated impact was 207.42 soles, while in the sub-periods 2007-2011, 2011-2015, and 2015-2019, they were 85.09 soles, 59.25 soles, and 56.88 soles. In the period 2003-2007, they were not significant (Table 3 ). These results are consistent with the hypothesis that the increase in the demand for labor in mining areas generated by the mining boom translates into an increase in local wages, regardless of whether workers are employed in mining or not (Hunter et al. 2014).

It should be noted that the sum of the impacts in subperiods coincides with the global impact of the period 2003 and 2019, which corroborates the adequate estimation of the results. The greatest impact of mining occurred in the period 2007-2011, which corresponds to the period of the third gold rush (2005-2012), where international prices registered the highest peaks. In order to illustrate the impact of mining, the model is written for the period 2003-2016 (column 6, Table 3), in the form of an equation: income of the districts without mining reached 555.38 soles, while in the districts with mining, it reached 787.33 soles. If the mining districts had not had mining, in 2019 the per capita family income would have been 579.91 soles. Therefore, the impact of mining on per capita family income is 207.42 soles.

Table 4 shows the results of the regression model that show the direct and indirect impact of mining on per capita family income when the spillover effect is taken into account. During the period 2003-2019 the total impact in the mining-producing district was 291.61 soles, being the direct impact of 189.77 and the indirect impact of 101.84 soles. Likewise, there is a total impact of 77.25 soles on the per capita income of the neighboring non-mining districts of the mining province, the indirect impact being 66.72 soles. In the sub-periods 2003-2007, 2007-2011, 2011-2015, and 2015-2019, the total impact of mining on per capita family income was 25.86 soles, 127.47 soles, 51.26 soles, and 101.48 soles, respectively, while the impact on neighboring non-mining districts was 46.07 soles in the 2007-2011 period and 28.89 soles in the 2015-2019 period, in the rest of the periods, it was not significant. These results corroborate the hypothesis of the existence of a spillover effect of mining on per capita income (Antoci et al. 2019; Loayza and Rigolini 2016). The interpretation of this effect could be explained by the employment that the

$y_{i}=478.86+24.53 D_{i}+291.66 T_{i}+207.42 *\left(D_{i} * T_{i}\right)+-0.09 *$ Altitude $_{i}-0.02 *$ Surface $_{i}+e_{i t}$

For an average altitude of $2237 \mathrm{~m}$ above sea level, an average area of $690 \mathrm{~km}^{2}$, Eq. (7), results

$y_{i}=263.72+24.53 D_{i}+291.66 T_{i}+207.42\left(D_{i} * T_{i}\right)+e_{i t}$

According to Fig. 5, in 2003, the districts without mining had an average per capita income of 263.72 soles while the mining districts 288,251 soles. In 2019 , the per capita family gold mining center generates positive "spillovers" in the geographic areas near and distant from such centers (Tello 2018). These results go in the direction of the findings of Loayza and Rigolini (2016), who find that mining activity in Peru has a positive impact on the per capita income/consumption of mining and non-mining districts. For its part, Kitula (2006), through a case study in the district of Geita in Tanzania, the average income in mining and non-mining 
Table 4 Impact of mining on per capita family income with spillover effect

\begin{tabular}{|c|c|c|c|c|c|c|}
\hline \multirow[t]{2}{*}{ Variable } & \multirow[t]{2}{*}{ Parameter } & \multicolumn{5}{|l|}{ Periods } \\
\hline & & 2003-2019 & 2003-2007 & $2007-2011$ & $2011-2015$ & 2015-2019 \\
\hline Constante & $\beta_{1}$ & $\begin{array}{l}464.237 * * * \\
(0.00)\end{array}$ & $\begin{array}{l}352.61 * * * \\
(0.00)\end{array}$ & $\begin{array}{l}379.16^{* * * *} \\
(0.00)\end{array}$ & $\begin{array}{l}600.00 * * * \\
(0.00)\end{array}$ & $\begin{array}{l}774.47 * * * \\
(0.00)\end{array}$ \\
\hline Mining district (D1) & $\beta_{2}$ & $\begin{array}{l}19.89 \\
0.12\end{array}$ & $\begin{array}{l}24.53 * * * \\
0.00\end{array}$ & $\begin{array}{l}25.68 * * \\
0.02\end{array}$ & $\begin{array}{l}116.68 * * * \\
0.00\end{array}$ & $\begin{array}{l}170.99 * * * \\
0.00\end{array}$ \\
\hline Non-mining district of the mining province (D2) & $\beta_{3}$ & $\begin{array}{l}40.05^{* * * *} \\
(0.00)\end{array}$ & $\begin{array}{l}25.49 * * * \\
(0.00)\end{array}$ & $\begin{array}{l}13.91 * \\
(0.10)\end{array}$ & $\begin{array}{l}43.03 * * * \\
(0.00)\end{array}$ & $\begin{array}{l}48.95 * * * \\
(0.00)\end{array}$ \\
\hline Mining canon (MC) & $\beta_{4}$ & $\begin{array}{l}-0.00 \\
(0.82)\end{array}$ & $\begin{array}{l}0.00 \\
(0.685)\end{array}$ & $\begin{array}{l}0.01 * \\
(0.00)\end{array}$ & $\begin{array}{l}-0.00 \\
(0.35)\end{array}$ & $\begin{array}{l}-0.00 \\
(0.68)\end{array}$ \\
\hline Year $(\mathrm{T})$ & $\gamma$ & $\begin{array}{l}302.10 * * * \\
(0.00)\end{array}$ & $\begin{array}{l}-44.97 * * * \\
(0.00)\end{array}$ & $\begin{array}{l}138.44^{* * * *} \\
(0.00)\end{array}$ & $\begin{array}{l}121.27 * * * \\
(0.00)\end{array}$ & $\begin{array}{l}100.11^{* * *} \\
(0.00)\end{array}$ \\
\hline Direct impact in mining district $(\mathrm{D} 1 * \mathrm{~T})$ & $\delta_{1}$ & $\begin{array}{l}189.77 * * \\
(0.00)\end{array}$ & $\begin{array}{l}2.84 \\
(0.66)\end{array}$ & $\begin{array}{l}83.59 * * * \\
(0.00)\end{array}$ & $\begin{array}{l}51.26^{* * *} \\
(0.00)\end{array}$ & $\begin{array}{l}55.09 * * * \\
(0.00)\end{array}$ \\
\hline $\begin{array}{l}\text { Direct impact in non-mining district of the mining province } \\
\text { (D2*T) }\end{array}$ & $\delta_{2}$ & $\begin{array}{l}10.52 \\
(0.55)\end{array}$ & $\begin{array}{l}-13.75^{* * *} \\
(0.00)\end{array}$ & $\begin{array}{l}22.05 * * * \\
(0.00)\end{array}$ & $\begin{array}{l}-2.22 \\
(0.75)\end{array}$ & $\begin{array}{l}4.33 \\
(0.40)\end{array}$ \\
\hline Altitud (A) & $\beta_{5}$ & $\begin{array}{l}-0.09 * * * \\
(0.00)\end{array}$ & $\begin{array}{l}-0.04 * * * \\
(0.00)\end{array}$ & $\begin{array}{l}-0.07 * * * \\
(0.00)\end{array}$ & $\begin{array}{l}-0.12^{* * *} \\
(0.00)\end{array}$ & $\begin{array}{l}-0.15^{* * *} \\
(0.00)\end{array}$ \\
\hline Surface $(S)$ & $\beta_{6}$ & $\begin{array}{l}-0.01 * * * \\
(0.00)\end{array}$ & $\begin{array}{l}-0.01^{* * * *} \\
(0.00)\end{array}$ & $\begin{array}{l}-0.01 * * * \\
(0.00)\end{array}$ & $\begin{array}{l}-0.013 * * * \\
(0.00)\end{array}$ & $\begin{array}{l}-0.02 \\
(0.00)\end{array}$ \\
\hline Indirect impact in mining district $(\mathrm{D} 1 * \mathrm{~T} * \mathrm{~W})$ & $\delta_{1}^{W}$ & $\begin{array}{l}101.84 * * * \\
0.00\end{array}$ & $\begin{array}{l}23.02 * * * \\
0.00\end{array}$ & $\begin{array}{l}43.88^{*} \\
0.06\end{array}$ & $\begin{array}{l}52.15^{* *} \\
0.02\end{array}$ & $\begin{array}{l}46.38 * * * \\
0.00\end{array}$ \\
\hline $\begin{array}{l}\text { Indirect impact in non-mining district of the mining province } \\
(\mathrm{D} 2 * \mathrm{~T} * \mathrm{~W})\end{array}$ & $\delta_{2}^{W}$ & $\begin{array}{l}66.72 * * * \\
(0.00)\end{array}$ & $\begin{array}{l}16.37 * * * \\
(0.00)\end{array}$ & $\begin{array}{l}24.01 * \\
(0.10)\end{array}$ & $\begin{array}{l}25.24 * * \\
(0.09)\end{array}$ & $\begin{array}{l}24.55 * * \\
(0.02)\end{array}$ \\
\hline Lag spatial $\left(\mathrm{W}^{*} \mathrm{e}\right)$ & $\lambda$ & $\begin{array}{l}0.86^{* * * *} \\
(0.00)\end{array}$ & $\begin{array}{l}0.97 * * * \\
(0.00)\end{array}$ & $\begin{array}{l}0.92 * * * \\
(0.00)\end{array}$ & $\begin{array}{l}1.04 * * * \\
(0.00)\end{array}$ & $\begin{array}{l}1.00 * * * \\
(0.00)\end{array}$ \\
\hline Total impact & & & & & & \\
\hline Total impact in mining district & $\delta_{1}+\delta_{1}^{W}$ & $\begin{array}{l}291.61 * * * \\
(0.00)\end{array}$ & $\begin{array}{l}25.86^{* * * *} \\
(0.00)\end{array}$ & $\begin{array}{l}127.47 * * * \\
(0.00)\end{array}$ & $\begin{array}{l}51.26^{* * * *} \\
(0.00)\end{array}$ & $\begin{array}{l}101.48 * * * \\
(0.00)\end{array}$ \\
\hline Total impact in non-mining district of the mining province & $\delta_{2}+\delta_{2}^{W}$ & $\begin{array}{l}77.25 * * * \\
(0.00)\end{array}$ & $\begin{array}{l}2.62 \\
(0.00)\end{array}$ & $\begin{array}{l}46.07 * * * \\
(0.00)\end{array}$ & $\begin{array}{l}-2.22 \\
(0.00)\end{array}$ & $\begin{array}{l}28.89 * * \\
(0.00)\end{array}$ \\
\hline Sigma_u & & $\begin{array}{l}69.62 * * * \\
(0.00)\end{array}$ & $\begin{array}{l}45.17 * * * \\
(0.00)\end{array}$ & $\begin{array}{l}83.82^{* * * *} \\
(0.00)\end{array}$ & $\begin{array}{l}154.23 * * * \\
(0.00)\end{array}$ & $\begin{array}{l}212.87 * * * \\
(0.00)\end{array}$ \\
\hline Sigma_e & & $\begin{array}{l}158.26^{* * * *} \\
(0.00)\end{array}$ & $\begin{array}{l}42.45^{* * * *} \\
(0.00)\end{array}$ & $\begin{array}{l}78.48 * * * \\
(0.00)\end{array}$ & $\begin{array}{l}59.82 * * * \\
(0.00)\end{array}$ & $\begin{array}{l}44.54 * * * \\
(0.00)\end{array}$ \\
\hline Number of obs & & 3638 & 3652 & 3662 & 3664 & 3730 \\
\hline Number of groups & & 1819 & 1826 & 1831 & 1832 & 1865 \\
\hline Obs per group & & 2 & 2 & 2 & 2 & 2 \\
\hline Wald chi $^{2}$ & & 1349.86 & 762.97 & 1178 & 1209 & 1612 \\
\hline Prob $>$ chi $^{2}$ & & $(0.00)$ & $(0.00)$ & $(0.00)$ & $(0.00)$ & $(0.00)$ \\
\hline Log likelihood & & -24148 & -20318.59 & -22562 & -23025 & -23230 \\
\hline Pseudo $R^{2}$ & & 0.43 & 0.23 & 0.36 & 0.34 & 0.34 \\
\hline Wald test of spatial terms & & & & & & \\
\hline $\begin{array}{l}\operatorname{chi}^{2}(3) \\
\text { Prob }>\operatorname{chi}^{2}\end{array}$ & & $\begin{array}{l}4070.05 \\
(0.00)\end{array}$ & $\begin{array}{l}27252.91 \\
(0.00)\end{array}$ & $\begin{array}{l}7756.67 \\
(0.00)\end{array}$ & $\begin{array}{l}2400000 \\
(0.00)\end{array}$ & $\begin{array}{l}170000 \\
(0.00)\end{array}$ \\
\hline
\end{tabular}


communities were US\$ 361.47 and US\$ 15.04, respectively. Likewise, they show that $66 \%$ and $3 \%$ of the average family income of mining and non-mining communities is derived from mining. In contrast, in Jordan, comparisons before and after mining, mining activities did not greatly benefit local communities in relation to the country as a whole (Al Rawashdeh et al. 2016).

Regarding the mining canon, the results suggest that the mining canon did not have a significant effect on per capita family income. This result is consistent with the finding of Franco (2020) who shows that mining canon transfers in Peru improve the standard of living of households only when they are high enough to achieve a real impact on the population. Specifically, it shows that households in districts that receive high amounts of mining royalties reduce their levels of deprivation compared to those that receive low amounts. In this line, Loayza and Rigolini (2016) show that the mining canon does not have a detrimental effect or benefit on the socioeconomic level of the population in Peru and suggest that the impact of mining on the socioeconomic level is related to the same activity economic more than the tax revenue that is generated. However, the authors estimate with data until 2007 when the disparity in the per capita mining canon was narrower.

The income from mining canon in Peru is distributed as follows: $10 \%$ for the local government of the producing district, $25 \%$ for all municipalities in the producing province, $40 \%$ for all municipalities in the producing department, $20 \%$ for the regional government, and 5\% for public universities of the producing department. The purpose of this distribution is to finance investment projects in the areas surrounding the mining exploitation in order to compensate them for the negative externalities generated by extraction; however, these projects do not always generate immediate effects on the well-being of the population.

\section{Conclusions}

Mining activity, during the period 2003-2019, shows a positive impact on the level of family income per capita in the mining-producing districts and neighboring districts belonging to the mining-producing province, being the greater impact in the producing district with respect to the impact in the neighboring district. In this sense, mining has played an important role in improving the income of the population of various districts in the interior of the country. In 2003, almost all of the districts with the highest per capita income were located on the coast of Peru, while in 2019, the districts with the highest income extend to some districts of the jungle and highlands of Peru.

The results show that the impact of mining on per capita family income in the mining-producing district was 207.42 soles; however, when considering the spatial spillover effect of mining, the total impact was 291.61 soles, which is decomposed into a direct effect of 189.77 soles and an indirect effect (spillover effect) of 101.84 soles. Likewise, there is a total of 77.25 soles on the per capita family income of the neighboring non-mining district and which the spillover effect is 66.72 soles. These results suggest that it is necessary to take into account the effect of mining spatial spillover.

In the departments with an important presence of informal gold mining such as Arequipa, Madre de Dios, and Puno, although there is an increase in the per capita income of the mining districts, due to the low economic contribution to the government of this type in mining, the transfer of mining canon received by local governments is not enough to carry out public investment projects. In this sense, it is suggested that the Regional Directorates of Energy and Mines put more effort into the process of formalizing small and artisanal miners.

In Peru, the dynamism of the mining sector in recent decades requires the development of a cluster around the mining industry, in order to promote the development of localities near the mining center and generate forward linkages (transformation of raw material into products with higher added value) and backward linkages (purchases of mining companies from local suppliers).

\section{Appendix}

\section{Table 5}

Table 5 Place of Perú in the worldwide ranking of mining production 2019

\begin{tabular}{lll}
\hline Product & Latin America & World \\
\hline Gold & 1 & 8 \\
Copper & 2 & 2 \\
Silver & 2 & 2 \\
Zinc & 1 & 2 \\
Lead & 1 & 3 \\
Tin & 1 & 4 \\
Molybdenum & 2 & 4 \\
Cadmium & 2 & 9 \\
Phosphoric rock & 2 & 10 \\
Diatomite & 1 & 6 \\
Indium & 1 & 7 \\
Kyanite and related minerals & 1 & 4 \\
Selenium & 1 & 11 \\
\hline
\end{tabular}

Source: US Geological Survey (USGS), Mineral Commodity Summaries, Febrero 2020

Elaboration: Ministerio de Energía y Minas 
Table 6 Domestic exports (millions of US\$)

\begin{tabular}{|c|c|c|c|c|c|c|c|c|c|c|}
\hline Product & 2010 & 2011 & 2012 & 2013 & 2014 & 2015 & 2016 & 2017 & 2018 & 2019 \\
\hline Metallic miner & 21,903 & 27,526 & 27,467 & 23,789 & 20,545 & 18,950 & 21,777 & 27,582 & 28,899 & 28,074 \\
\hline Non-metallic minerals & 252 & 492 & 722 & 722 & 664 & 698 & 640 & 588 & 629 & 604 \\
\hline Sidero-metallurgists and jewelry & 949 & 1,130 & 1,301 & 1,320 & 1,149 & 1,081 & 1,084 & 1,273 & 1,325 & 1,310 \\
\hline Metal-mechanical & 393 & 476 & 545 & 544 & 581 & 533 & 445 & 520 & 591 & 558 \\
\hline Oil and natural gas & 3,088 & 4,568 & 4,996 & 5,271 & 4,562 & 2,302 & 2,213 & 3,369 & 4,039 & 2,974 \\
\hline Fisheries (traditional exports) & 1,884 & 2,114 & 2,312 & 1,707 & 1,731 & 1,457 & 1,269 & 1,789 & 1,938 & 1,929 \\
\hline Agricultural & 975 & 1,689 & 1,095 & 786 & 847 & 723 & 878 & 827 & 762 & 774 \\
\hline agriculture and livestock & 2,203 & 2,836 & 3,083 & 3,444 & 4,231 & 4,409 & 4,702 & 5,146 & 5,913 & 6,341 \\
\hline Fisheries (non-traditional exports) & 644 & 1,049 & 1,017 & 1,030 & 1,155 & 933 & 909 & 1,046 & 1,329 & 1,564 \\
\hline Textiles & 1,561 & 1,990 & 2,177 & 1,928 & 1,800 & 1,331 & 1,196 & 1,272 & 1,402 & 1,354 \\
\hline Woods and papers & 359 & 402 & 438 & 427 & 416 & 353 & 322 & 344 & 339 & 321 \\
\hline Chemicals & 1,228 & 1,655 & 1,636 & 1,510 & 1,515 & 1,406 & 1,342 & 1,385 & 1,562 & 1,600 \\
\hline Others & 364 & 451 & 622 & 381 & 336 & 239 & 243 & 282 & 339 & 285 \\
\hline Total & 35,803 & 46,376 & 47,411 & 42,861 & $\mathbf{3 9 , 5 3 3}$ & 34,414 & 37,020 & 45,422 & 49,066 & 47,688 \\
\hline
\end{tabular}

Souce: MINEM (2019)

Table 6

Table 7 Participation of mining exports

\begin{tabular}{|c|c|c|c|c|c|c|c|c|c|c|}
\hline Product & 2010 & 2011 & 2012 & 2013 & 2014 & 2015 & 2016 & 2017 & 2018 & 2019 \\
\hline Mining exports $1 /$ & $61.90 \%$ & $60.40 \%$ & $\mathbf{5 9 . 5 0 \%}$ & $\mathbf{5 7 . 2 0 \%}$ & $53.60 \%$ & $57.10 \%$ & $60.60 \%$ & $62.00 \%$ & $60.20 \%$ & $60.10 \%$ \\
\hline Metallic miner & $61.20 \%$ & $59.40 \%$ & $\mathbf{5 7 . 9 0 \%}$ & $\mathbf{5 5 . 5 0 \%}$ & $52.00 \%$ & $55.10 \%$ & $\mathbf{5 8 . 8 0} \%$ & $60.70 \%$ & $58.90 \%$ & $\mathbf{5 8 . 9 0 \%}$ \\
\hline Non-metallic minerals & $0.70 \%$ & $1.10 \%$ & $1.50 \%$ & $1.70 \%$ & $1.70 \%$ & $2.00 \%$ & $1.70 \%$ & $1.30 \%$ & $1.30 \%$ & $1.30 \%$ \\
\hline Rest of exports & $38.10 \%$ & $39.60 \%$ & $40.50 \%$ & $42.80 \%$ & $46.40 \%$ & $42.90 \%$ & $39.40 \%$ & $38.00 \%$ & $39.80 \%$ & $39.90 \%$ \\
\hline Sidero-metallurgists and jewelry & $2.65 \%$ & $2.44 \%$ & $2.74 \%$ & $3.08 \%$ & $2.91 \%$ & $3.14 \%$ & $2.93 \%$ & $2.80 \%$ & $2.70 \%$ & $2.75 \%$ \\
\hline Metal-mechanical & $1.10 \%$ & $1.03 \%$ & $1.15 \%$ & $1.27 \%$ & $1.47 \%$ & $1.55 \%$ & $1.20 \%$ & $1.15 \%$ & $1.20 \%$ & $1.17 \%$ \\
\hline Oil and natural gas & $8.63 \%$ & $9.85 \%$ & $10.54 \%$ & $12.30 \%$ & $11.54 \%$ & $6.69 \%$ & $5.98 \%$ & $7.42 \%$ & $8.23 \%$ & $6.24 \%$ \\
\hline Fisheries (traditional exports) & $5.26 \%$ & $4.56 \%$ & $4.88 \%$ & $3.98 \%$ & $4.38 \%$ & $4.23 \%$ & $3.43 \%$ & $3.94 \%$ & $3.95 \%$ & $4.04 \%$ \\
\hline Agricultural & $2.72 \%$ & $3.64 \%$ & $2.31 \%$ & $1.83 \%$ & $2.14 \%$ & $2.10 \%$ & $2.37 \%$ & $1.82 \%$ & $1.55 \%$ & $1.62 \%$ \\
\hline agriculture and livestock & $6.15 \%$ & $6.11 \%$ & $6.50 \%$ & $8.04 \%$ & $10.70 \%$ & $12.81 \%$ & $12.70 \%$ & $11.33 \%$ & $12.05 \%$ & $13.30 \%$ \\
\hline Fisheries (non-traditional exports) & $1.80 \%$ & $2.26 \%$ & $2.14 \%$ & $2.40 \%$ & $2.92 \%$ & $2.71 \%$ & $2.45 \%$ & $2.30 \%$ & $2.71 \%$ & $3.28 \%$ \\
\hline Textiles & $4.36 \%$ & $4.29 \%$ & $4.59 \%$ & $4.50 \%$ & $4.55 \%$ & $3.87 \%$ & $3.23 \%$ & $2.80 \%$ & $2.86 \%$ & $2.84 \%$ \\
\hline Woods and papers & $1.00 \%$ & $0.87 \%$ & $0.92 \%$ & $1.00 \%$ & $1.05 \%$ & $1.03 \%$ & $0.87 \%$ & $0.76 \%$ & $0.69 \%$ & $0.67 \%$ \\
\hline Chemicals & $3.43 \%$ & $3.57 \%$ & $3.45 \%$ & $3.52 \%$ & $3.83 \%$ & $4.09 \%$ & $3.62 \%$ & $3.05 \%$ & $3.18 \%$ & $3.36 \%$ \\
\hline Others & $1.02 \%$ & $0.97 \%$ & $1.31 \%$ & $0.89 \%$ & $0.85 \%$ & $0.69 \%$ & $0.66 \%$ & $0.62 \%$ & $0.69 \%$ & $0.60 \%$ \\
\hline Total & $100 \%$ & $100 \%$ & $100 \%$ & $100 \%$ & $100 \%$ & $100 \%$ & $100 \%$ & $100 \%$ & $100 \%$ & $100 \%$ \\
\hline
\end{tabular}

$1 /$ includes exports of metallic (traditional) and non-metallic (non-traditional) mining products

Souce: MINEM (2019)

Table 7 


\section{Declarations}

Human and animal rights The research does not involving human participants and/or animals.

Conflict of interest The authors declare no competing interests.

Open Access This article is licensed under a Creative Commons Attribution 4.0 International License, which permits use, sharing, adaptation, distribution and reproduction in any medium or format, as long as you give appropriate credit to the original author(s) and the source, provide a link to the Creative Commons licence, and indicate if changes were made. The images or other third party material in this article are included in the article's Creative Commons licence, unless indicated otherwise in a credit line to the material. If material is not included in the article's Creative Commons licence and your intended use is not permitted by statutory regulation or exceeds the permitted use, you will need to obtain permission directly from the copyright holder. To view a copy of this licence, visit http://creativecommons.org/licenses/by/4.0/.

\section{References}

Al Rawashdeh R, Campbell G, Titi A (2016) The socio-economic impacts of mining on local communities: the case of Jordan. Ext Ind Soc 3(2):494-507. https://doi.org/10.1016/j.exis.2016.02.001

Anselin L (1988) Spatial econometrics: methods and models. Stud Oper Reg Sci. https://doi.org/10.1007/978-94-015-7799-1

Antoci A, Russu P, Ticci E (2019) Mining and local economies: dilemma between environmental protection and job opportunities. Sustainability (Switzerland) 11(22):1-21. https://doi.org/10. 3390/su11226244

Argota G, Argota H, Mamani J (2014) Determinación analítica por exposición a cianuro libre en efluentes mineros, planta artesanal poderosa Ananea - Puno. Cátedra Villarreal 1(2):11-18. https:// doi.org/10.24039/cv20142123

Aron AS, Molina O (2020) Green innovation in natural resource industries: the case of local suppliers in the Peruvian mining industry. Ext Ind Soc 7(2):353-365. https://doi.org/10.1016/j.exis.2019. 09.002

Balanay RM, Yorobe JM, Reyes SG, Mae A, Ordem C (2014) Analyzing the socio-economic impacts of mining with propensity score matching ( PSM ): insights for responsible mining in. Dev Country Stud 4(13):11-21

Bernal RS and Peña X (2011) Guía práctica para la evaluación de impacto. (E. Uniandes, Ed.), Universidad de los Andes. Bogotá: Facutad de Economía, Centro de Estudios sobre Desarrollo Económico

Cano A (2020) cano_roncagliolo.pdf. The University of British Columbia

Cortés-McPherson D (2019) Expansion of small-scale gold mining in Madre de Dios: 'capital interests' and the emergence of a new elite of entrepreneurs in the Peruvian Amazon. Ext Ind Soc 6(2):382389. https://doi.org/10.1016/j.exis.2019.01.002

Dammert A and Molinelli F (2007). Panorama de la Minería en el Perú. Osinergmin

Espejo JC, Messinger M, Román-Dañobeytia F, Ascorra C, Fernandez LE, Silman M (2018) Deforestation and forest degradation due to gold mining in the Peruvian Amazon: a 34-year perspective. Remote Sensing 10(12):1-17. https://doi.org/10.3390/rs10121903

Gamu J, Le Billon P, Spiegel S (2015) Extractive industries and poverty: a review of recent findings and linkage mechanisms. Ext Ind Soc 2(1):162-176. https://doi.org/10.1016/j.exis.2014.11.001
Hunter B, Howlett M and Gray M (2014) The economic impact of the mining boom on indigenous and non-indigenous australians (No. 93/2014). Retrieved from https://caepr.cass.anu.edu.au/sites/defau 1t/files/docs/WP93_Hunter_Howlett_Gray_Mining_0.pdf

IPE (2021) Contribución de la minería a la economía nacional. Lima, Perú

Kitula AGN (2006) The environmental and socio-economic impacts of mining on local livelihoods in Tanzania: a case study of Geita District. J Clean Prod 14(3-4):405-414. https://doi.org/10.1016/j. jclepro.2004.01.012

Landa Y (2017) Revenue from the extractive industries and copper mining in Peru. Problemas Del Desarrollo 48(189):141-168. https://doi.org/10.1016/j.rpd.2017.04.007

Loayza N, Rigolini J (2016) The local impact of mining on poverty and inequality: evidence from the commodity boom in Peru. World Dev 84:219-234. https://doi.org/10.1016/j.worlddev.2016.03.005

Maldonado S (2011) Boom Minero Y Corrupción de Funcionarios Públicos de los Gobiernos Locales en el Perú: Evidencia de Un Experimento Natural. CIES. Lima, Perú

Manrique H and Sanborn C (2021) La minería en el Perú: balance y perspectivas de cinco décadas de investigación. La minería en el Perú: balance y perspectivas de cinco décadas de investigación. Lima, Perú. https://doi.org/10.21678/978-9972-57-458-0

MINAM (2016) La lucha por la legalidad en la actividad minera (20112016). Ministerio del Ambiente - Perú. Lima, Perú. Retrieved from https://www.actualidadambiental.pe/que-pasaria-si-se-derog an-las-normas-mas-importantes-sobre-mineria-ilegal-e-informal/

MINEM (2017) Catálogo de Medidas mbientales en el marco del IGAFOM. Lima, Perú. Retrieved from http://www.minem.gob.pe/_ detalle.php?idSector $=20 \&$ idTitular $=8216 \&$ idMenu $=$ sub7996\& idCateg $=1487$

MINEM (2019) Anuario 2019. Minesterio de Energia y Minas. Lima. Retrieved from http://www.minem.gob.pe/_publicacion.php? idSector $=1 \&$ idPublicacion $=599$

MINEM (2021) REINFO. Minem. Lima, Perú

Nolazco J and Figueroa T (2015) Impacto de la dinámica en la industria minera sobre el desarrollo regional de Arequipa: Un análisis de género. Lima, Perú

Osinergmin (2017) La industria de la minería en el Perú: 20 años de contribución al crecimiento y desarrollo económico del país. (A. y V. Z. o Tamayo, Jesús; Salvador, Julio; Vásquez, Ed.). Lima, Perú. Retrieved from http://www.osinergmin.gob.pe/seccion/ centro_documental/mineria/Documentos/Publicaciones/Osine rgmin-Industria-Mineria-Peru-20anios.pdf

Osumanu IK (2020) Small-scale mining and livelihood dynamics in north-eastern Ghana: sustaining rural livelihoods in a changing environment. Prog Dev Stud 20(3):208-222. https://doi.org/10. 1177/1464993420934223

Seeger M (2019) Mining capital. Min Capital. https://doi.org/10.1007/ 978-3-030-31225-1_2

Sidorenko O, Sairinen R, Moore K (2020) Rethinking the concept of small-scale mining for technologically advanced raw materials production. Resour Policy 68(July):101712. https://doi.org/10. 1016/j.resourpol.2020.101712

Tello MD (2018). Empleo en industrias extractivas del Perú: un análisis espacial o geográfico. Economía, XLI(81), 9-34. https://doi.org/ 10.18800/economia.201801.001

Ticci E, Escobal J (2015) Extractive industries and local development in the Peruvian Highlands. Environ Dev Econ 20(1):101-126. https://doi.org/10.1017/S1355770X13000685

Torres V (2015) Minería Ilegal e Informal en el Perú: Impacto Socioeconómico. World Business Council for Sustainable Development. Retrieved from http://cooperaccion.org.pe/wp-content/uploads/ 2015/10/Libro_Mineria_Ilegal, Victor Torres Cuzcano.pdf

Vargas V (2014) Actividad Minera en el Peru. Definiciones. Ministerio de Energía y Minas. Lima, Perú. Retrieved from https:// 
wedocs.unep.org/bitstream/handle/20.500.11822/13096/PERU_-_ PNUMA_ONUDI_FORO_PPA_PMA.pdf? sequence=1\&isAll owed $=\mathrm{y}$

Wiener L (2019) Manual sobre la formalización de la Minería en Pequeña Escala. (Cooperacción, Ed.), Cooperacción (Primera).
Lima, Perú. Retrieved from http://cooperaccion.org.pe/wp-conte nt/uploads/2019/06/Formalización-Minera.pdf

Publisher's note Springer Nature remains neutral with regard to jurisdictional claims in published maps and institutional affiliations. 